\title{
Quality assessment of solid biofuel made of sweet sorghum biomass
}

\author{
Tatiana Ivanova ${ }^{1, *}$, Alexandru Muntean ${ }^{1}$, Bohumi Havrland $^{1}$, and Petr Hutla ${ }^{2}$ \\ ${ }^{1}$ Czech University of Life Sciences Prague, Faculty of Tropical AgriSciences, Department of Sustainable Technologies, \\ Kamýcká 129, 16521 Prague 6, Czech Republic \\ ${ }^{2}$ Research Institute of Agricultural Engineering, Drnovská 507, 16101 Prague 6, Czech Republic
}

\begin{abstract}
The present article relates to assessment of energy utilization of sweet sorghum waste biomass as solid biofuel (briquettes). The briquettes were produced from biomass of pure sweet sorghum after juice extraction, mixture of sorghum with wood sawdust (ratio 1:1) and mixture of sorghum with wood shavings (ratio 1:1). Chemical, physical and mechanical properties of produced briquettes were measured in accordance with appropriate standards. The research results showed that the mixed sorghum briquettes with wood shavings have the highest mechanical durability and the lowest ash content; on the other hand, briquettes made of sweet sorghum and wood sawdust havethe best values of all other parameters, including higher calorific values, density, etc. Although addition of residual wood biomass improved the general quality of sorghum based briquettes, it was stated that the briquettes made of pure processed sorghum stalks belong to the category of high quality agricultural solid biofuels. It can be concluded that sweet sorghum is of very good prospects and thus it is a promising biomass feedstock for solid biofuels production (not only for the production of liquid biofuel as it has been used by today and has been known before).
\end{abstract}

\section{Introduction}

Bioenergy, i.e. energy produced in the field or gained from waste biomass is one of promising trends in agricultural engineering research that merits higher attention of researchers and investments into application of its results. This is because the increasing energy consumption leads at present to a fast shrinking fossil fuel deposits and strong environment pollution probably reflecting in warming up the Earth's atmosphere. Therefore, there is a need to utilizing alternative energy resources including biomass and biomass-based biofuels [1]. Biomass of energy crops has been gaining a considerably wide energy application during recent years [2]. Due to high biomass yields with a high sugar content (fermentable saccharides) as compared to other crops yielding sugar or starch like sugarcane, wheat or corn, the sweet sorghum gives a very attractive raw material for the liquid biofuel - bioethanol production [3]. According to [4] and [5] sweet sorghum has on average 85-90\% sugar fermentation efficiency for bioethanol.

Sorghum (Sorghum bicolor (L).Moench), including sweet sorghum, is one of the longest growing crops, it is widely adapted to diverse environments and grows almost everywhere in the world [6]. Sorghum is multipurpose plant, also called $4 \mathrm{~F}$ crop, because it is used for fuel, food, fodder and feed [5]. In the world cereal's rank sorghum is in the fifth place following corn, rice, wheat and barley as useful to human daily need [7]. Sweet sorghum is annual or short perennial plant and according to growing conditions and varieties, it reaches a height of about $120-400 \mathrm{~cm}$ [8]. Sorghum is C4 crop with high photosynthetic efficiency. It accumulates carbon dioxide during the night and then has a lower photorespiration rate during the day that reduces waste of carbon and water [9]. In most of tropical and temperate countries, where sugar cane or corn cannot grow, sweet sorghum is growing well and tolerates salinity and drought $[7,10]$. As confirmed by [5] that sweet sorghum has low water requirements for high yield, as comparing to sugarcane, which requires three times more. Sweet sorghum resists to biotic and abiotic factors. It has low requirement for fertilizers, one third of sugar cane or corn need in the same conditions [11]. Sweet sorghum is concerned as low inputs and low costs crop [12, 13], which has many advantages in contrast to other energy crops.

Sweet sorghum has been considered as a particular energy crop for production of bioethanol since 1970s. It has high yield of biomass $\left(54-69 \mathrm{t} \mathrm{ha}^{-1}\right)$, i.e. stalks with high sugar content [14]. Amount of the main substances that compose sweet sorghum stalk as carbohydrates (glucose, sucrose and fructose) often depends and changes according to the maturity stage, cultivar and harvesting period [15]. Nevertheless, growing production and consumption of bioethanol generates large quantities of waste biomass remaining from sorghum processing - sugar juice extraction [10]. In

Corresponding author: ivanova@ftz.czu.cz 
accordance with [16] residual biomass from sweet sorghum contents mainly cellulose 34-44\%, hemicellulose $25-27 \%$ and lignin $18-20 \%$. Crushed residual stalks were burnt by [17] to generate electricity or steam. But for a more efficient combustion residue obtained from sorghum processing should be used in a form of compacted solid biofuel. Sweet sorghum is important for refined sugar and bioethanol production. Effective use of waste biomass can contribute to additional lowering of sugar production costs and good waste to energy management.

The main objective of this research is the analysis of potential and suitability of sweet sorghum biomass after juice extraction to be used for energy purposes in the form of solid biofuels, particularly as briquettes.

\section{Material and methods}

For experimental purposes of this research the briquettes (three kinds of briquettes) were produced from the following feedstock materials:

1)Briquettes from sweet sorghum without any blender addition or any mixing with other crops. This type was made of sweet sorghum stalks in dry and grinded form after sugar juice extraction. For briquetting $10 \mathrm{~kg}$ of biomass with moisture content $12 \%$ was used, abbreviated as sample $\mathrm{S}_{0}$.

2)Mixed briquettes made of $50 \%$ of sweet sorghum stalk and $50 \%$ of wood sawdust, named as $\mathrm{SW}_{1}$.

3)Mixed briquettes made of $50 \%$ sweet sorghum stalk and $50 \%$ of wood shavings, assigned as $\mathrm{SW}_{2}$.

Sweet sorghum biomass used for the research purposes was shipped from Moldova. The briquettes were produced by hydraulic piston briquetting press BrikStar 50-12 (Briklis, Czech Republic) with working pressure $18 \mathrm{MPa}$ and a cylindrical matrix of $65 \mathrm{~mm}$ in diameter.

Fractional composition (particle size distribution) of sweet sorghum biomass used for briquetting was done by sieve analysis method according to EN 15149-1:2011and it is presented in the Figure 1.

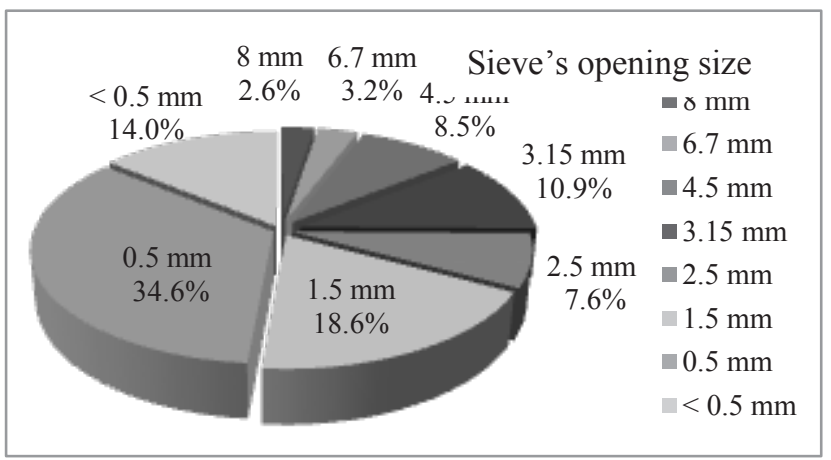

Fig. 1. Particle size distribution of sweet sorghum biomass used in experiment

All required briquettes' parameters were measured in the laboratory according to the methodology given by EN and ISO standards for solid biofuels.

Determination of moisture content $(w)$ of briquettes as well as initial raw biomass was performed according to EN ISO 18134-2:2015 and EN ISO 18134$3: 2015$,respectively. Tested samples were dried out at $105^{\circ} \mathrm{C}$ in laboratory oven Memmert $100-800$ and the following equation was used for calculation:

$$
w=\frac{m_{2}-m_{3}}{m_{2}-m_{1}} \times 100, \%
$$

where: $m_{l^{-}}$mass of empty crucible, g; $m_{2}-$ mass of crucible with sample before drying, g; $m_{3}-$ mass of crucible with sample after drying, $g$.

The gross calorific value (GCV) for dry basis (d.b.) and as received (a.r.) samples was measured by bomb calorimeter Laget MS-10A according to EN 14918:2009and was calculated by simplified equation $[18,19]$ :

$$
G C V=\frac{d T k \times T k-c}{m}, \mathrm{~J} \mathrm{~g}^{-1}
$$

where: $d T k$ - temperature jump, ${ }^{\circ} \mathrm{C} ; T k$ - mean value of the effective heat capacity of the calorimeter as determined in the calibrations $\left(9,161 \mathrm{~J}^{\circ} \mathrm{C}^{-1}\right) ; c$ - total repair (repair on benzoic acid plus repair on burning spark fine wire), $\mathrm{J} ; m$-weight of material sample, $g$.

For calculation of net calorific value (NCV) from gross calorific value was used equation applied by [20]:

$$
N C V=G C V-24.53 \times(w+9 H), \mathrm{J} \mathrm{g}^{-1}
$$

where: 24.53 - heat of water evaporation; $w$ - moisture content of the sample, \%; 9 - coefficient for conversion of hydrogen to water, $H$ - hydrogen content in the sample, $\%$.

It should be mentioned that according to [21] moisture content has significant impact on a net calorific value of solid biofuels and the quality of biofuel largely depends on the moisture content of initial raw material. Calorific value of briquettes also depends on the origin and treatment of the feedstock material, especially on material's particle size. Other authors [22] have stated that solid biofuel with high density have a higher calorific value.

Briquettes' average dimensions (length and diameter) were measured by digital calliper and their density $(\rho)$ was simply calculated by the equation (4):

$$
\rho=\frac{m}{\pi \times r^{2} \times l}, \mathrm{~kg} \mathrm{~m}^{-3}
$$

where: $m$ - weigh of the briquette, $\mathrm{kg} ; r-\mathrm{D} / 2$ half of the diameter, $\mathrm{m} ; l$ - length of the briquette, $\mathrm{m}$.

Mechanical durability (DU) of produced briquettes was determined using a special rotary drum in accordance with standard EN ISO 17831-2:2015and was calculated as follows:

$$
D U=\frac{m_{A}}{m_{E}} \times 100, \%
$$

where: $m_{A}-$ mass of sieved briquettes after the drum treatment, $g ; m_{E}-$ mass of pre-sieved briquettes before the drum treatment, g. 
Proximate analysis (ash content and volatile matter) and ultimate analysis $(\mathrm{C}, \mathrm{H}, \mathrm{O}, \mathrm{N}, \mathrm{S}$ and $\mathrm{Cl})$ of tested briquettes were performed as well.

In case of ash content measurements, the standard EN ISO 18122:2015was respected and ash content $(A)$ of dry samples was calculated by the equation (6):

$$
A=\frac{\left(m_{3}-m_{1}\right)}{\left(m_{2}-m_{1}\right)} \times 100, \%
$$

where: $m_{1}-$ mass of empty dish, g; $m_{2}-$ mass of dish plus test sample, $\mathrm{g} ; m_{3}-$ mass of dish plus ash, $\mathrm{g}$.

Determination of volatile matter content $\left(V_{d}\right)$ was done in accordance with standard EN ISO 18123:2015and the following equation was used for calculation (7):

$$
V_{d}=\left[\frac{100 \times\left(m_{2}-m_{3}\right)}{\left(m_{2}-m_{1}\right)}-w\right] \times\left(\frac{100}{100-w}\right), \%
$$

where: $m_{1}$ - weight of empty vessel, g; $m_{2}$ - weight of vessel with sample before heating, $g ; m_{3}-$ weight of vessel with sample after heating, $\mathrm{g} ; w$ - moisture content, $\%$.

Chemical elements were determined according to the respective standards: EN ISO 16948:2015for carbon, hydrogen, nitrogen and EN ISO 16994:2015 for chlorine and sulfur. Oxygen content was then calculated.

\section{Results and discussion}

Quality of solid biofuels depends on number of parameters. These parameters could be divided into two groups: chemical properties and physic-mechanical properties.

In the Table 1, all parameters assessed in this research are presented and compared to the approximate values given by solid biofuels standards.

From the Table 1 is visible that all produced briquettes showed very good quality, i.e. briquettes made of pure sweet sorghum biomass fulfil standard requirements for graded non-wooden briquettes and according to the stated parameters belong to A quality class (the best one). It was found that $\mathrm{S}_{0}$ briquettes have relatively high gross and net calorific values, low ash content and the contents of all measured chemical elements below limits. Gross calorific values (w.b. and a.r.) of pure sweet sorghum stalk briquettes correspond to gross calorific values of sorghum biomass published by other authors, for example $17.9 \mathrm{MJ} \mathrm{kg}^{-1}$ [23] or 17-19 MJ $\mathrm{kg}^{-1}[14]$. Compared to other sources of biomass: $\mathrm{GCV}_{\text {d.b. }}$ of sorghum is higher than $\mathrm{GCV}_{\text {d.b. }}$ of hay (grass in general) - $18 \mathrm{MJ} \mathrm{kg}^{-1}$ [21], switchgrass or corn stover - $17.3 \mathrm{MJ} \mathrm{kg}^{-1}$ [24] and it is almost equal to $\mathrm{GCV}_{\text {d.b. }}$ of famous energy crop Miscanthus - $19 \mathrm{MJ} \mathrm{kg}^{-1}$, however lower than $\mathrm{GCV}_{\text {d.b. }}$ of wood logging residues $-19.7 \mathrm{MJ}$ $\mathrm{kg}^{-1}$ (broad-leaf wood) and $20.5 \mathrm{MJ} \mathrm{kg}^{-1}$ (coniferous wood) (EN ISO 17225-1:2014).

The research results showed very good (low) value of ash content in $\mathrm{S}_{0}$ briquettes (see Table 1). According to [25] ash content of herbaceous biomass reaches values up to $10 \%$, for example ash content of hay found by [26] is $6.3 \%$, which is almost twice higher in comparison with sorghum. On the other hand, ash content of graded wood briquettes should not exceed maximum 3\% (EN ISO 17225-3:2014). As [27] reported that low ash content leads to better suitability of fuels for thermal utilization in contrast to a fuel with high ash content. High ash content causes high dust emissions and negatively affects combustion efficiency.

Another fuel parameter, which has an impact of combustion process, is volatile matter. According to [28] high volatile matter (from 70 to $86 \%$ ) improves the combustion rate of the biomass during the devitalization phase. On the contrary, low volatile matter causes high smoke within incomplete combustion and release toxic gases. [29]published that the values of carbon content in biomass, which can be used as a fuel vary between 30 $60 \%$, for hydrogen $5-6 \%$, for oxygen $30-40 \%$ and for the rest elements less than $1 \%$. By [21] carbon, hydrogen and oxygen are the main components of solid fuels, which directly contribute to the fuel combustion (affecting calorific value). Chlorine, nitrogen and sulphur have an effect on ash formation as well as significantly impact on the formation of harmful emissions, mainly mono-nitrogen oxides $\left(\mathrm{NO}_{\mathrm{x}}\right)$ and sulphur oxide $\left(\mathrm{SO}_{\mathrm{x}}\right)$ and highly corrosive hydrochloric acid $(\mathrm{HCl})[21,30]$. Taking into account all above mentioned facts, it can be concluded that briquettes from sweet sorghum biomass seem to be very suitable for a clean and efficient combustion.

From the Table 1 is also visible that addition of wood residual biomass, i.e. production of mixed briquettes improves the total quality of sweet sorghum based briquettes, including chemical and physic-mechanical properties. The mixed briquettes are more compact as confirms briquettes dimensions and density. The addition of wood sawdust showed slightly better results, except for mechanical durability and ash content, which are insignificantly better in case of briquettes enriched with wood shavings.

The differences between mechanical durability of $\mathrm{SW}_{1}$ and $\mathrm{SW}_{2}$ can be caused by different fraction composition, i.e. particle size distribution of the initial raw materials and joining mechanisms between different sized particles during mechanical compaction (briquetting). [31] reported that the compacted briquettes made of raw materials with larger particles $(>6 \mathrm{~mm})$ have usually better hardness and briquettes densification in general. Sweet sorghum biomass used for the experimental purposes contains of particles smaller than $6.7 \mathrm{~mm}$ from more than $97 \%$, where almost $70 \%$ of the particles are smaller than $1.5 \mathrm{~mm}$ (see Fig. 1). Hence, the addition of larger particles into the mixtures or crushing the sorghum through bigger screens can have a positive impact on mechanical durability. Mechanical durability is not presented as a normative parameter in the solid biofuels standards; nevertheless, high mechanical durability is preferable as it is a measure of resistance of densified fuels towards shocks and/or abrasion in consequence of transport and handling processes [32]. 
Table 1. Determined properties of briquettes based on sweet sorghum biomass and typical standards' requirements.

\begin{tabular}{|c|c|c|c|c|c|c|}
\hline \multirow[t]{3}{*}{ Parameter } & \multicolumn{3}{|c|}{ Briquette type } & \multicolumn{3}{|c|}{ Standard requirements* } \\
\hline & \multirow[t]{2}{*}{$\overline{\mathbf{S}_{\mathbf{0}}}$} & \multirow[t]{2}{*}{$\mathbf{S W}_{1}$} & \multirow[t]{2}{*}{$\overline{\mathbf{S W}_{2}}$} & \multirow{2}{*}{$\begin{array}{c}\text { Typical } \\
\text { variations }\end{array}$} & \multicolumn{2}{|c|}{ Property class $^{2}$} \\
\hline & & & & & $\mathbf{A}$ & B \\
\hline Moisture content, a.r., $\%$ & 7.7 & 7.3 & 7.9 & - & $\leq 12$ & $\leq 15$ \\
\hline Ash content, d.b, $\%$ & 3.9 & 2.2 & 2.1 & $2-10$ & $\leq 6$ & $\leq 10$ \\
\hline Volatile matter, d.b. $\%$ & 70.8 & 76.3 & 75.5 & - & - & - \\
\hline GCV d.b., $\mathrm{MJ} \mathrm{kg}^{-1}$ & 18.9 & 19.7 & 19.5 & $16.6-20.1$ & - & - \\
\hline GCV a.r., $\mathrm{MJ} \mathrm{kg}^{-1}$ & 17.7 & 18.6 & 18.2 & - & - & - \\
\hline NCV d.b., $\mathrm{MJ} \mathrm{kg}^{-1}$ & 17.7 & 18.4 & 18.2 & $15.8-19.1$ & - & - \\
\hline $\mathrm{NCV}$ a.r., $\mathrm{MJ} \mathrm{kg}^{-1}$ & 16.3 & 17.1 & 16.7 & - & $\geq 14.5$ & $\geq 14.5$ \\
\hline Length, mm & 77.4 & 49.4 & 51.7 & $<50$ to $>400$ & - & - \\
\hline Diameter, mm & 66.9 & 66.1 & 66.8 & 25 to $>125$ & - & - \\
\hline Mechanical durability, $\%$ & 90.5 & 94.1 & 95.1 & $<90$ to $\geq 95$ & - & - \\
\hline Briquettes density $\left(\mathrm{kg} \mathrm{m}^{-3}\right)$ & 617.5 & 745.9 & 645.5 & - & - & - \\
\hline C, d.b. $\%$ & 43.1 & 45.7 & 45.4 & $41-50$ & - & - \\
\hline H, d.b. $\%$ & 5.27 & 6.02 & 6.08 & $5.4-6.5$ & - & - \\
\hline O, d.b. $\%$ & 37.3 & 39.0 & 38.9 & $36-45$ & - & - \\
\hline $\mathrm{N}$, d.b. $\%$ & 0.61 & 0.32 & 0.34 & $0.2-1.5$ & $\leq 1.5$ & $\leq 2.0$ \\
\hline S, d.b. $\%$ & 0.04 & 0.03 & 0.03 & $<0.05$ to 0.2 & $\leq 0.20$ & $\leq 0.30$ \\
\hline $\mathrm{Cl}$, d.b. $\%$ & 0.09 & 0.06 & 0.08 & $<0.1$ to 1.2 & $\leq 0.10$ & $\leq 0.30$ \\
\hline
\end{tabular}

*I Typical variations were obtained from European standard for solid biofuels EN 14961-1 (2010) - for virgin straw materials, with or without insignificant amounts of grains;

${ }^{2}$ Specification of graded non-woody briquettes for property classes A and B according to EN ISO 17225-7 (2014); a.r. - as received; d.b. - dry basis; $\mathrm{S}_{0}$ - pure sweet sorghum briquettes, $\mathrm{SW}_{1}$ - mixed briquettes from sweet sorghum and wood sawdust (1:1); $\mathrm{SW}_{2}$ - mixed briquettes from sweet sorghum and wood shavings $(1: 1)$.

According to EN 14961-1 (2010) $\mathrm{S}_{0}$ and $\mathrm{SW}_{1}$ briquettes have a medium category mechanical durability DU90.0 and $\mathrm{SW}_{2}$ briquettes reached the highest category durability DU95.0 (see Table 1). Besides the material fraction, compaction pressure is another factor which affects the mechanical durability, i.e. with increasing pressure durability of the briquettes increase [32]. Low pressure used during the briquettes production had probably impact on final briquette density as well, which is relatively low for all briquettes' types. [33] stated that too low pressure produces poor quality of briquettes. For example, screw presses have higher density of briquettes. On the other hand, therefore higher pressure used for briquetting produces briquettes with better mechanical properties (dense and durable), but much energy is spent [32].

\section{Conclusions}

Usage of suitable waste biomass in the form of biofuels for energy purposes contributes to the support of renewable energy development, replacement of pollutant and limited fossil fuels, protection of forest reserves as well as it has positive social/energy/environmental impact and leads to sustainable development. Sweet sorghum is almost worldwide spread crop with high biomass yield. The big advantage of sorghum biomass utilization for solid biofuels' production is in an effective recycling of waste from the bioethanol production, which reflects on good waste management and makes the sweet sorghum processing waste-free technology.
Based on references review and research results, the sweet sorghum waste biomass can be evaluated as very promising feedstock for solid biofuel (briquettes) production. All three types of briquettes produced from sweet sorghum and tested during this study showed very good quality, which fulfil the standard requirements. Briquettes made of pure sorghum processed stalks are characterized by high calorific value, low ash content and low content of chlorine, nitrogen and sulfur. The study also concludes that the addition of woody biomass, i.e. wood sawdust and wood shavings improve overall quality of sorghum based briquettes. Two weakest parameters of sorghum briquettes which were found by the research measurements and are recommended to be improved, i.e. mechanical durability and briquettes' density (mechanical parameters), are not such decisive in biofuel's quality assessment as they can be technologically improved and do not depend on the biomass properties like other parameters.

The study was supported by the Internal Grant Agency of the Faculty of Tropical AgriSciences, Czech University of Life Sciences Prague, research grant number 20165012 and 20175011. Acknowledgements also belong to Ing. TsotsoAkofa Mensah for her appreciable help with laboratory works.

\section{References}

1. R.P. Srinivasa, S.S. Rao, N. Seetharama, A.V. Umakanth, P.S. Reddy, B.V.S. Reddy, Ch.L. Gowda, Sweet sorghum for biofuel and strategies 
for its improvement,Info. Bull. No. 77 (International Crops Research Institute for the Semi-Arid Tropics, Andhra Pradesh, 2009)

2. C. Zhang, G. Xie, S. Li, L. Ge, T. He, Appl. Energy 87, 2360-2368 (2010)

3. Reddy, B.V.S., S. Ramesh, P.S. Reddy, B. Ramaiah, P.M. Salimath, R. Kachapur, ISMN 4,79-86 (2005)

4. S. Prasad, A. Singh, N. Jain, H.C. Joshi, Energy Fuels 21, 2415-2420 (2007)

5. A. Almodares, M.R. Hadi, J Agric Res 4, 772-780 (2009)

6. F.S.K.N. Rai, B.V.S. Reddy, B. Diwakar, Development of cultivars and seed production techniques in sorghum and pearl millet(International Crops Research Institute for the Semi-Arid Tropics, Andhra Pradesh, 1997)

7. C.W. Smith, R.A.Frederiksen, Sorghum: origin, history, technology and production(John Wiley \& Sons, Inc., New York, 2000)

8. Q. Lu, Song, R., Lu, F. 1997. Rainfed Crops 4, 1923 (1997)

9. J.E. Keeley, P.W. Rundel, Int. J. Plant Sci. 164, 5577 (2003)

10. J. Woods, Integrating sweet sorghum and sugarcane for bioenergy: modelling the potential for electricity and ethanol production in SE Zimbabwe (King's College, London, 2000)

11. M. Kim, D.F. Day, J IndMicrobiolBiotechnol 38, 803-807 (2011)

12. EIA, International Energy Outlook 2011. Report No. DOE/EIA-0484(Energy Information Administration, Washington, 2011)

13. M. Calvino, J. Messing, CurrOpinBiotechnol 23, 323-329 (2012)

14. A. Almodares, M. Jafarinia, M.R. Hadi, AmericanEurasian J. Agric. \& Environ. Sci. 6, 441-446 (2009)

15. D. Mamma, D. Koullas, G. Fountoukidis, D. Kekos, B.J. Macris, E. Koukios, Process Biochem. 31, 377381 (1996).

16. B. Sipos, J. Réczey, Z. Somorai, Z. Kádár, D. Dienes, K. Réczey, Appl. Biochem. Biotechnol. 153,151-162 (2009)

17. W. Vermerris, J. Erickson, D. Wright, Y. Newman, C. Rainbolt, IFAS, SS AGR 293: 1-4 (2008)

18. B. Havrland, T. Ivanova, B. Lapczynska-Kordon, M. Kolarikova, $12^{\text {th }}$ International scientific conference Engineering for rural development, Jelgava, 541-544 (2013)

19. T. Ivanova, A. Muntean, V. Titei, B. Havrland, M. Kolarikova, Agron. Res. 13, 311-317 (2015)

20. T. Dlouhý, Calculations of boilers and flue gas heat exchangers(Czech Technical University in Prague, Prague, 2007)

21. P. Jevič, P. Hutla, Z. Šedivá, Sustainable production and quality control of solid fuels based on agricultural bioproducts(Research Institute of Agricultural Engineering, Prague, 2008)

22. J.S. Tumuluru, C.T. Wright, J.R. Hess, K.L. Kenney, Biofuel BioprodBior 5, 683-707 (2011)

23. J. Kára, Z. Strašil, P. Hutla, S. Ust'ak, Energy crops. Technology for growing and use(Research Institute of Agricultural Engineering, Prague, 2005)

24. J.S. Tumuluru, Front. Energy Res. 3, 1-7 (2015)

25. A. Kotlánová, Biom.cz, Available at http://biom.cz/cz/odborne-clanky/metody-zkousenifyzikalne-chemickych-vlastnosti-tuhych-biopaliv (2010).

26. P. Hutla, Biom.cz, Available at http://biom.cz/cz/odborne-clanky/tuha-biopaliva-zmistnich-zdroju (2010)

27. H.J. Kim, G.Q. Lu, I. Naruse, J. Yuan, K. Ohtake, J. EnergyResour. Technol1 23, 27-31 (2000)

28. S.V. Loo, J. Koppejan. The handbook of biomass combustion and co-firing. Earthscan, London, Sterling, VA, 2008)

29. J. Chaney, Combustion characteristics of biomass briquettes (University of Nottingham, Nottingham, 2010)

30. J.S. Tumuluru, J.R. Hess, R.D. Boardman, C.T. Wright, T.L. Westover, IndBiotechnol 8, 113-132 (2012)

31. Y. Song, J.S. Tumuluru, K.L. Iroba, L.G. Tabil, M. Xin, V. Meda, XVII ${ }^{\text {th }}$ World congress of the International Commission of Agricultural and Biosystems Engineering, Quebec, 1-14 (2010)

32. T. Ivanova, M. Kolarikova, B. Havrland, L. Passian, $13^{\text {th }}$ International scientific conference Engineering for rural development, Jelgava, 131-136 (2014)

33. B. Havrland, V. Pobedinschi, V. Vrancean, J. Pecen, T. Ivanova, A. Muntean, A. Kandakov, Biomass processing to biofuel(Powerprint, Prague Chisinau, 2011) 